\title{
Tumor Suppressor Protein
}

National Cancer Institute

\section{Source}

National Cancer Institute. Tumor Suppressor Protein. NCI Thesaurus. Code C20982.

Proteins involved in the regulation of cell growth and prevention of uncontrolled cell growth. 